\title{
超高層集合住宅用ディスポーザ排水配管システムの性能検証手法に関する研究 ESTIMATION METHOD OF DRAINAGE PIPING SYSTEMS WITH FOOD WASTE GRINDERS IN HIGH-RISE APARTMENT HOUSES
}

\author{
新 村 浩 一*, 大塚 雅 之**, 山海敏 弘***, 長 野晃 弘**** \\ Kouichi SHINMURA, Masayuki OTSUKA, Toshihiro SANKAI \\ and Akihiro NAGANO
}

\begin{abstract}
We examined estimation method of drainage piping systems in order to apply wastewater treatment systems with food waste grinders to real high-rise appartment houses. The piping systems were set up in the high-rise experimental tower, had drainage stack of $90 \mathrm{~m}$ height and house drain of $90 \mathrm{~m}$ length, were supposed the models in real buildings. In this study we investigated how facters influence the performance and pressure in branch, were 4 types forms of drainage fittings, and 2 types diameters of grind garbage particles or characteristics of discharge by food waste grinders. Further we examined influence of offset in lower floor, relief vent pipe for back pressure in stack closure at the bend, and house drain length. As a result, special drainage fittings systems are able to decrease negative pressure than usual sanitary $\mathrm{T}$ fittings system, using food waste grinders break to pieces finely are able to decrease positive pressure than using its break to pieces roughly, and offset has effect of making horizontal transport smooth, were found.
\end{abstract}

Keywords : drainage piping system with food waste grinders, high-rise apartment houses, drainage fitting, grind particles diameters, offset, house drain ディスポーザ排水配管システム, 超高層集合住宅, 排水継手, 破砕粒度, オフセット, 排水横主管

\section{1..はじめに}

土地の高度有効利用を目的とした超高層集合住宅の建設は，主に 首都圈で実施されている再開発プロジェクトの中心的な役割をなす ものである。特に都心型の超高層型居住において，日常生活で発生 する生ごみは家庭ごみの $33.2 \%{ }^{6)}$ を占めること，保管や運搬に係る 労力も要することから, 合理的な処理設備の開発は, 今後の超高層 集合住宅設備の課題と言える。その方策の一つとしてディスポーザ 排水処理システムがあげられ，有機質資源としてのリサイクル利用 の可能性も考えると，スケールメリットが期待できる超高層集合住 宅で，その可否が問われている。同システムの性能評価は，先に旧 建設省綕合技術開発プロジェクト「ディスポーザーによる生ごみリ サイクルシステムの開発」の一環として実施されてきだ。しかしな がら,そこではディスポーザ本体や排水処理槽の性能評価が中心で, 排水立て管や排水横主管などの配管系統については 4 層程度の中層 規模の配管モデルに限定されており，超高層集合住宅に適用する場 合の安全性，すなわち封水損失や管内圧力といった指標に基づく排 水能力を検証するまでには至らなかった。

その後, 高層集合住宅を対象とした幾つかの特殊継手排水システ
ムに関する赛験は実施されたが8,9)，超高層集合住宅を対象とした検 討事例は非常に少ない。特に超高層用の既往の排水実験では，参考 となる実験条件や設計上の留意点は示されているが10,11)，沉用性の 高い成果として実務的に用いるには，次のような課題点が指摘でき る。先ず，実験に用いた特殊継手排水システムとディスポーザの種 類が限定されていること，更には，実際の超高層排水配管でみられ る下層階でのオフセット配管，排水立て管基部の正圧緩和用に計画 されることが多い逃がし通気管，排水横主管の配管長などの要因が 充分に加味されていないことから，それらが性能に及ぼす影響が定 量的に把握できていない点である。

よって本報では, 高さ $90 \mathrm{~m}$ 規模の排水立て管と長さ $90 \mathrm{~m}$ 規模の排 水横主管を有する超高層集合住宅用ディスポーザ排水配管システム を一つの実在モデルとして想定し，排水用継手形状，ディスポーザ の破砕粒度と排出特性, オフセット配管, 逃がし通気管, 排水横主 管が，同システムの排水性能に及ぼす影響を超高層排水実験タワー を用いて実験的に検討した。その結果から, 今後, 超高層排水配管 システムの性能試験法を策定する際や，配管設計を行う上で重要な 留意点を提示することを目的とする。

\footnotetext{
* 三機工業侏技術研究所 所員

兼 関東学院大学大沢記念建築設備工学研究所 研究員

*** 関東学院大学工学部建築設備工学科, 助教授. 工博

**** 国土交通省国土技術政策総合研究所建築研究部 室長

**** 三機工業侏技術研究所 グループマネージャ・工博
}

R \& D Division, Sanki Engineering Co., Ltd.

Osawa Memorial Institute of Architectural Environmental Engineering, KantoGakuin Univ.

Assoc. Prof., Dept. of Architectural Environmental Engineering, Kanto-Gakuin Univ., Dr. Eng.

Building Research Institute, National Institute for Land and Infrastracture Management

R \& D Division, Sanki Engineering Co., Ltd., Dr. Eng. 


\section{2. 実験方法}

\section{1 供試排水配管システム}

実験は，都市基盤整備公団技術センタ一内にある超高層住宅実験 タワー（地上 37 階規模，高さ $108 \mathrm{~m}$ ）で行った。供試排水配管システ 厶を，図 1 に示す。排水立て管（管径 $100 \mathrm{~mm}$ ）は，負荷最上階 34 階 から 3 階の脚部継手までの高さ $93 \mathrm{~m}$ とした。 3 階部では，排水立て 管基部に長さ $6.5 \mathrm{~m}$ の排水横主管（以下，一次排水横主管，同図(c))
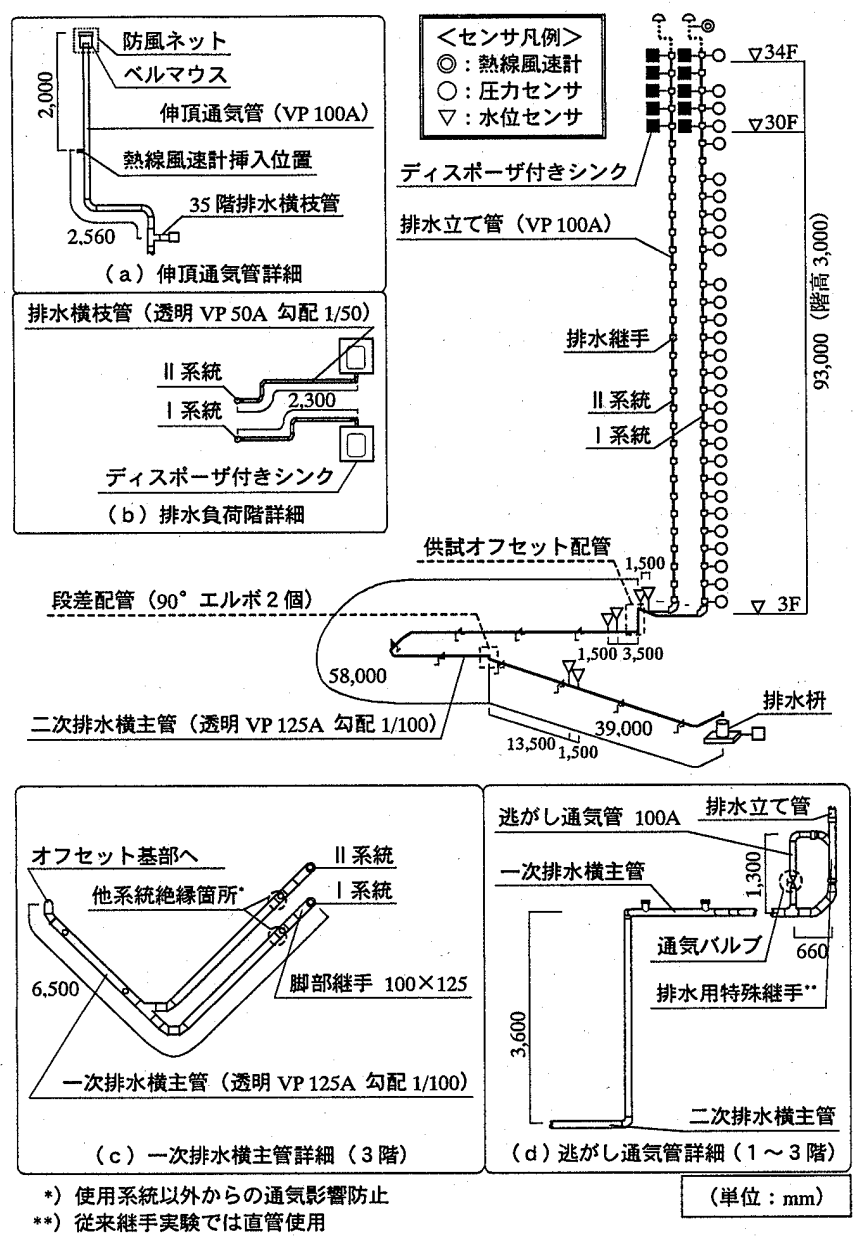

図 1 供試排水配管システム

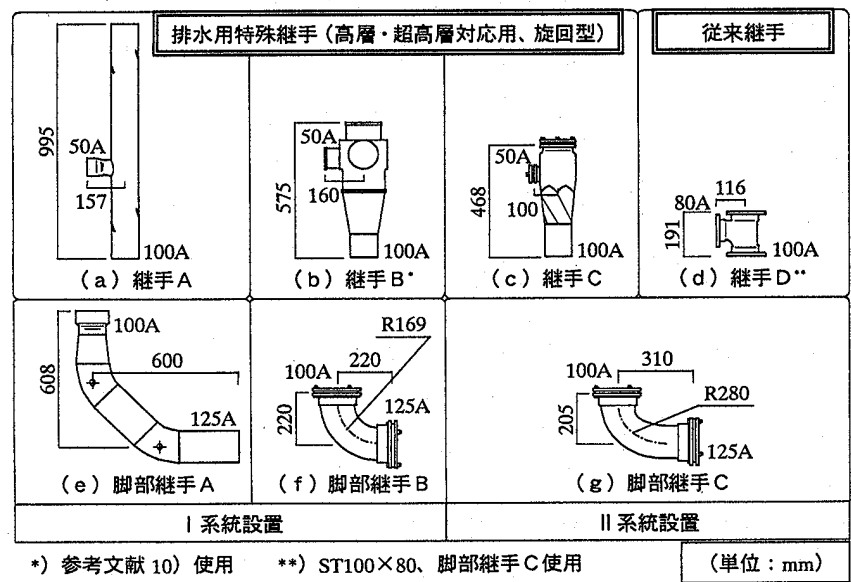

図 2 供試排水継手
を接続し，その終点から高低差 $3.6 \mathrm{~m}$ の落とし込み配管 (同図(d)) を 行っており，この部分を供試オフセット配管と呼ぶ。この端部に接 続する排水横主管（以下，二次排水横主管）は，途中に $45^{\circ}$ の横曲が クを 6 籄所設置し, $58 \mathrm{~m}$ 地点に落差 $0.35 \mathrm{~m}$ の段差配管を設置し, オ フセット基部から排水妌まで全長 $97 \mathrm{~m}$ とした。また，排水立て管は， 取り替えの都合上後述の図 2 の継手 A と B の実験時に I 系統を, 継手 CとDの実験時にII系統を使用した。

各部位の詳細については，伸頂通気管部を同図(a)に，排水負荷階 となる排水横枝管を同図(b)に，一次排水横主管の平面を同図(c)k， 排水立て管基部からオフセット基部までの立面を同図(d)にそれぞれ 示す。排水立て管基部迴りの通気バルブの開閉により, 逃がし通気 管の有無を設定した。

供試排水継手として，排水立て管継手と脚部継手の寸法図を図 2 に示す。排水立て管継手は, 同図(a) ( c) の高層・超高層対応用の旋 回型排水用特殊継手 3 種と, 同図(d)の従来型 ST 継手 1 種の合計 4 種類とした。この 3 種の排水用特殊継手は, 市販される中で形状お よび性能が代表的なものである ${ }^{12)}$ 。また, 結果を比較する際には, 排 水用特殊継手 B を用いて先に実施した参考文献10)の実験結果も引 用し，検討した。

\section{2 供試ディスポーザ}

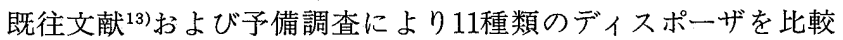
し，メジアン粒径が $0.6 \mathrm{~mm}$ 未満となる最小のもの(機種 $\mathrm{A}$ ，バッチ 式), $2.0 \mathrm{~mm}$ となる最大のもの(機種 $\mathrm{B}$, 連続式)の 2 機種を供試ディ スポーザとした非1)。その破砕粒度分布について, 既往文献 ${ }^{13)}$ に準じて 測定した結果を図 3 に示す。また，同機種の器具排水特性として累 積器具排水量 $w[\mathrm{~L}]$, 器具平均排水流量 $q_{d}[\mathrm{~L} / \mathrm{s}]$, および破砕時間 $t[\mathrm{~s}]$ について，既往文献 ${ }^{13)}$ に準じて測定した結果を表 1 に示す。破 砕時間 $t$ は, 破砕粒度の細かい機種 $\mathrm{A}$ が76秒に対し; 粗い機種 B で

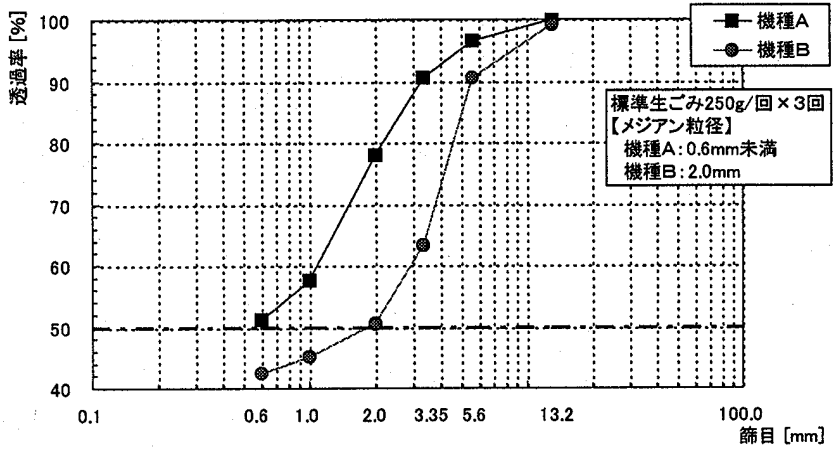

図 3 供試ディスポーザの破砕粒度分布

表 1 供試ディスポーザの器具排水特性

\begin{tabular}{|c|c|c|}
\hline & 機種 $\mathrm{A}$ & 機種 $\mathrm{B}$ \\
\hline メジアン粒径 $[\mathrm{mm}]$ & 0.6 未満 & 2.0 \\
\hline 累積器具排水量 $w[\mathrm{~L}]$ & 11.4 & 6.4 \\
\hline 器具平均排水流量 $q_{d}[\mathrm{~L} / \mathrm{s}]$ & 0.13 & 0.13 \\
\hline 破碎時間 $t[\mathrm{~s}]$ & 76 & 40 \\
\hline
\end{tabular}

*) メジアン粒径は測定 3 回の平均値、その他は測定 5 回の平均值

**) 破砕時間 $t$ は、既往文献 ${ }^{13)}$ での騒音レベル記録結果を読みとって求める 方法と異なり、ディスポーザの稼働時間を次式により求めた。 $t=\left(w / q_{d}\right)-10 \quad(10=$ 破砕前後の給水時間 $)$ 
は40秒と短い時間で生ごみを排出するので排出特性も異なる。

\section{3 排水負荷条件}

（1）単独負荷条件：参考文献10）を参考に, 最大同時排水個数 $M$, 負荷の与之方等を決定した。その結果， $M=5$ 個となるため, ディ スポーザ付きシンクを, 負荷最上階34階から30階までの各階に 1 個 ずつ計 5 個設置した。この単独負荷条件を，表 2 に示す。投入生ご み量は, ディスポーザ 1 個あたりに標準生ごみ $250 \mathrm{~g}$ とした。給水方

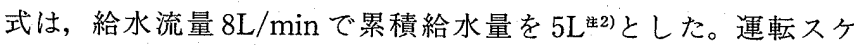
ジュール管理は制御盤を用い，ディスポーザ運転と電磁弁の給水を 同時に開始し, 負荷最上階から下層へと0.5秒ずつ遅らせて排水を開 始し, 37.5秒後き3引停止した。この運転方法を同時排水とみなした。

（2）単独過負荷条件：生ごみ量を $500 \mathrm{~g}$ とした場合の, 逃がし通気 管の効果を把握した。その他の条件は，前項と同じとした。

（3）合流負荷条件：一次排水横主管で 2 系統の排水立て管から排 水を合流させた場合の，逃がし通気管の効果を把握した。継手 $\mathrm{A}$ 設 置のI 系統は，主管として影響を確認するものとし，継手 C 設置の II系統は，合流管として排水を流すのみに用いた。この合流負荷条 件を, 表 3 に示す。累積給水量を 1 個あたり $35 \mathrm{~L}$ とし, 合流管の運転 開始から 20 秒後に，主管で 5 個同時排水した。

\section{4 測定方法}

（1）管内風速：伸頂通気管端部のベルマウスから $2 \mathrm{~m}$ の位置（図 1 (a)）に熱線風速計（範囲 $0.05 \sim 10 \mathrm{~m} / \mathrm{s}$ ，誤差 $\pm 0.2 \mathrm{~m} / \mathrm{s}$ ) を設置し，

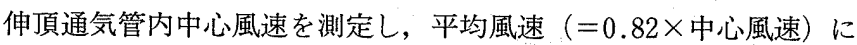
換算した。

（2）管内圧力：排水立て管中心から $250 ５ 00 \mathrm{~mm}$ の排水横枝管上 部で，4〜34階のうち22階，28階，33階を除いた階に，拡散型半導

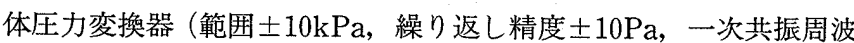
数 $6 \mathrm{kHz}$ 以上) を設置し，排水横枝管内圧力を測定した。排水負荷階 の圧力は，排水横枝管での満流による影響が生じないよう配慮し， 排水用特殊継手では 2 ロ夕イプに接続したキャップ止めによる排水 横枝管，従来継手では排水横枝管を $50 \mathrm{~mm}$ から $80 \mathrm{~mm}$ に拡径した後 部にセンサを設置した。各階の圧力変動から, 各階の最大正圧と最 大負圧を読みとった。HASS218 ${ }^{15}$ に準拠し，その值からシステム最 大值とシステム最小値を読みとり, $\pm 400 \mathrm{~Pa}$ 以内におさまることを 検証した。
表 2 単独目荷条件

\begin{tabular}{|c|c|}
\hline $\begin{array}{c}\text { 最大同時排水個数 } \\
\mathbf{M}^{10)}\end{array}$ & $\begin{array}{l}5 \text { 個 }(30 \sim 34 \text { 階 }) \\
\quad M=Q_{L} / q_{d}=4.1 / 0.75=5.47 \rightarrow 5 \\
Q_{L}: \text { 定常流量法からら算出した負荷流量 }{ }^{14)} \quad[\mathrm{L} / \mathrm{s}] \\
q_{d}: \text { 台所流しの器具平均排水流量 }{ }^{14)}[\mathrm{L} / \mathrm{s}]\end{array}$ \\
\hline 投入生ごみ ${ }^{10)}$ & 標準生ごみ $250 \mathrm{~g} /$ 個 (一人一日の排出量に相当 $\left.{ }^{7)}\right)$ \\
\hline 給水方式 & 1 個あたり $8 \mathrm{~L} / \mathrm{min}^{10)} \times 37.5 \mathrm{~s}(5 \mathrm{~L} /$ 個） \\
\hline 運転スケジュール & $\begin{array}{l}\text { (1)実験開始前に生ごみ投入 } \\
\text { (2)制御盤の運転ボタンと計測を同時に開始 } \\
\text { 345 }\end{array}$ \\
\hline
\end{tabular}

表 3 、合流負荷条件

\begin{tabular}{|c|c|}
\hline 排水立て管 & $\begin{array}{l}\text { 主 管：I 系統に継手 Aを設置 } \\
\text { 合流管：II 系統に継手 Cを設置 }\end{array}$ \\
\hline 投入生ごみ & 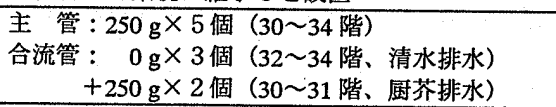 \\
\hline 給水方式 & 1 個あたり $8 \mathrm{~L} / \mathrm{min} \times 262.5 \mathrm{~s} （ 35 \mathrm{~L} /$ 個） \\
\hline 運転スケジュール & 合流管 5 個同時排水、 20 秒後に主管 5 個同 \\
\hline
\end{tabular}

（3）管内水位：排水立て管基部から $4.5 \mathrm{~m}$ と $6 \mathrm{~m}$ の一次排水横主 管上部（図 1 (c))，オフセット基部から $3.5 \mathrm{~m}$ と $5 \mathrm{~m}$ および $71.5 \mathrm{~m}$ と $73 \mathrm{~m}$ の二次排水横主管上部（図 1 ）に，超音波式変位センサ（範囲 $60 \sim 300 \mathrm{~mm} ，$ アナログ出力精度 $\pm 7.5 \mathrm{~mm}$ ）を設置し，排水横主管内 水位を測定した。この水位変動から, 水位センサ間の平均速度とし て搬送速度 (=水位センサ間距離 $1.5 \mathrm{~m} /$ 水位の立ち上がり時間差)を 求めた。

（4）残留状況：排水横主管での残留物の有無を目視確認した。

上記(1)〜(3)のアナログ信号を $\mathrm{AD}$ 変換器 (確度士0.2\%) とパソコ ンにより $100 \mathrm{~Hz}$ サンプリングした。サンプリングは, 制御盤運転開 始ボタンと同時に開始した。生データは, 管内圧力と管内水位にロー パスフィルタ $(3 \mathrm{~Hz}$ ，バタワース型）をかけ，デジタル処理した。

\section{3. 結果および考察}

\section{1 排水継手形状の影響}

図 4 は，図 2 の 4 種類の供試排水継手を用いた場合（機種 $\mathrm{A}$ ，単 独負荷条件 (生ごみ量 $250 \mathrm{~g} の 5$ 個同時排水)) の，伸頂通気管内平均
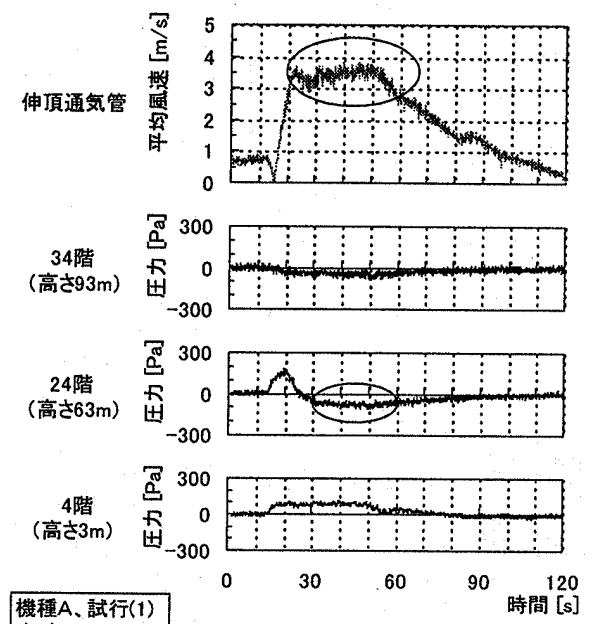

生ごみ: $250 \mathrm{~g} \times 5$
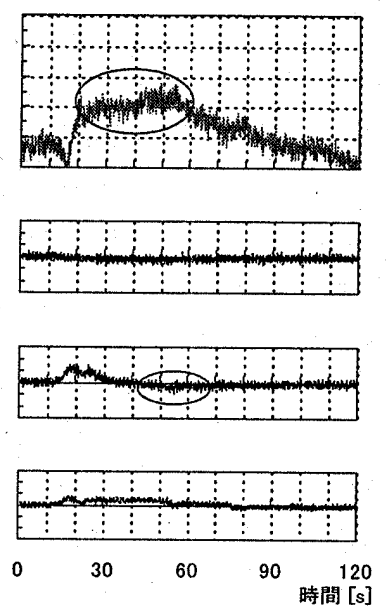

(b) 継手 $\mathrm{B}$
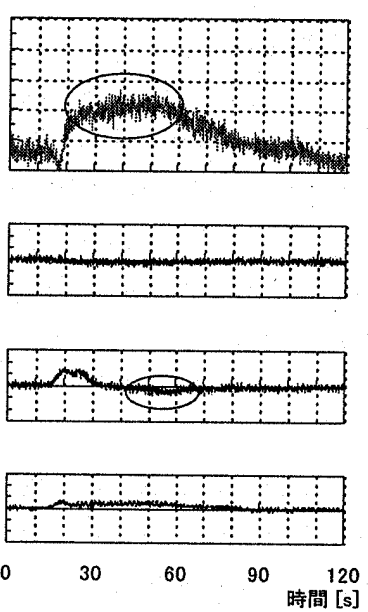

(c) 継手 C
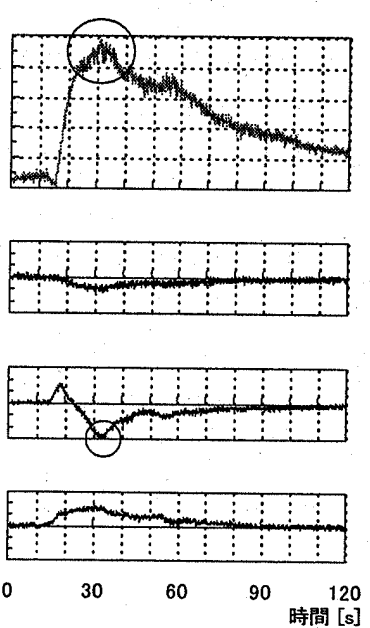

(d) 継手D

図 4 排水継手による平均風速変動・压力変動の比較 
風速および，34階，24階，最下階 4 階の管内圧力変動を示したもの である。同図より, 風速の最大值は, 従来継手 D が最も大きく, 次 いで排水用特殊継手 $\mathrm{A}$, 排水用特殊継手 $\mathrm{B}$ および $\mathrm{C}$ が同程度で小さ い。また, 伸頂通気管内の圧力損失指標となる34階の圧力変化がい ずれも小さいことから, 風速変化は排水流下速度の指標とみなせる。 これより, 流下速度の最大值は継手 D, A, B·Cの順に小さく, 旋 回羽根が大きいほど減速効果が著しいことが推察できる。基準とな る從来継手 D でシステム最小值が発生した24階の圧力を例に比較 すると, どの継手においても一旦最大正圧まで增加した後に, 最大 負圧まで減少する特徵がみられるが, 従来継手 D では排水用特殊継 手 $\mathrm{A} \sim \mathrm{C}$ の場合と比べ急激に減少している。また, 最下階 4 階の圧力 を比較すると,この程度の負荷では, どの継手においても明瞭なピー クがみられない。

圧力変動から各階の最大正圧・負圧を読みとり, 圧力分布を示し たのが図 5 である。同図より，11２6階の範囲の負圧は, 従来継手 Dで大きく変化しているのに对し, 排水用特殊継手 A C C゙は変化 がみられない。その平均值は，排水用特殊継手 $\mathrm{A}$ でー $114 \mathrm{~Pa}$ (標準 偏差 $\sigma=4 \mathrm{~Pa})$, 排水用特殊継手 $\mathrm{B}$ でー $77 \mathrm{~Pa}(\sigma=6 \mathrm{~Pa})$, 排水用特殊 継手 $\mathrm{C} て ゙ ー 76 \mathrm{~Pa}(\sigma=5 \mathrm{~Pa})$ となり， $\sigma$ 值も小さいので変化は小さく 一定とみなせる。排水用特殊継手 $\mathrm{A} \sim \mathrm{C}$ の正圧は, 下層になるほど減 少する傾向がみられる。

同図からシステム最大值・最小值を読みとり, 示したのが四 6 で ある。同図より，4 種類のシステム共に判定值士 $400 \mathrm{~Pa}$ 以内におさ まっているが, 従来継手 D では一 $291 \mathrm{~Pa}$ で判定值の $73 \%$ に達する。 しかし, 排水用特殊継手 A は $-122 \mathrm{~Pa}$ で30\%, 排水用特殊継手 B と C はほぼ同等の-83〜-91Pa で21〜23\%となり, 負圧が大きく緩和 されている。また，同一の排水用特殊継手 B を用いた今回と参考文 献10)の結果を比較すると, 今回の方が正圧は $161 \mathrm{~Pa}$ と大きく, 負圧 は-91Pa と小さい。これは, 排水横主管長さが参考文献10)では20 $\mathrm{m}$ あるのに对し, 今回は $107.1 \mathrm{~m}$ (排水立て管基部以降の全長) と長 いため, その排水横主管の通気抵抗が影響したものと推察される。 今回は実施していないが実際の台所系統では, 洗い桶を用いた溜め 排水等の厳しい負荷が加わるため, 従来継手 D では更に危険度が高 まり，判定值を超える可能性もある。よって以降では，従来継手を 対象から除き, 排水用特殊継手の中で判定值との比が最も厳しい継 手 Aを用いて検討する。

\section{2 ディスポーザ破砕粒度と排出特性の影響}

図 7 に，表 1 に示した破砕粒度と排出特性の異なる 2 種類のディ スポーザを用いた場合（継手 A， 単独負荷条件（生ごみ量 $250 \mathrm{~g}$ の 5 個同時排水)）の，各階の最大正圧・負圧を読みとった圧力分布を示 す。同図より, 破砕粒度の細かい機種 A では, 粗い機種 B よりも正 圧が各階ともに小さくなる。これは，破砕時間が長い機種 $\mathrm{A}$ では， 破砕厨芥がゆっくりと排出されることから，排水立て管に流入する スラリ濃度が緩和された影響と推察できる。逆に負圧は, 機種 Aが 各階ともに大きくなる。

図 8 に, システム最大值・最小值を示す。同図より，両機種とも 判定值以内であるが, 負圧側に比べ正圧側に大きい。正圧は, 機種

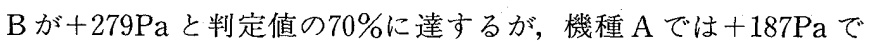
$47 \%$ となり, 機種 Bの方が大きい。よって以降では, 正圧に厳しい 条件となる機種 B を中心に検討する。

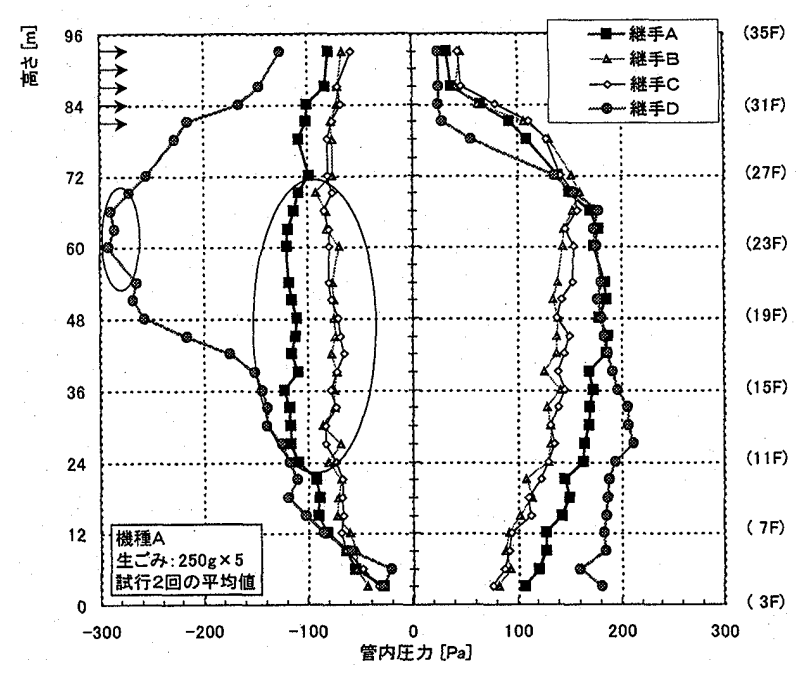

図 5 排水継手による圧力分布の比較

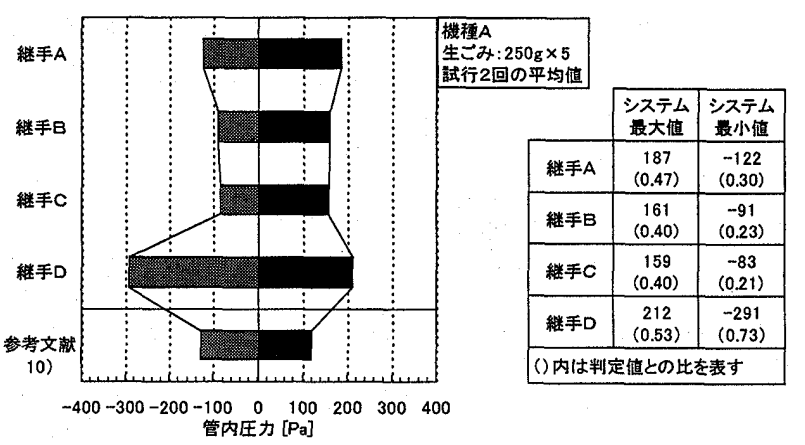

図 6 排水継手形状の圧力影響

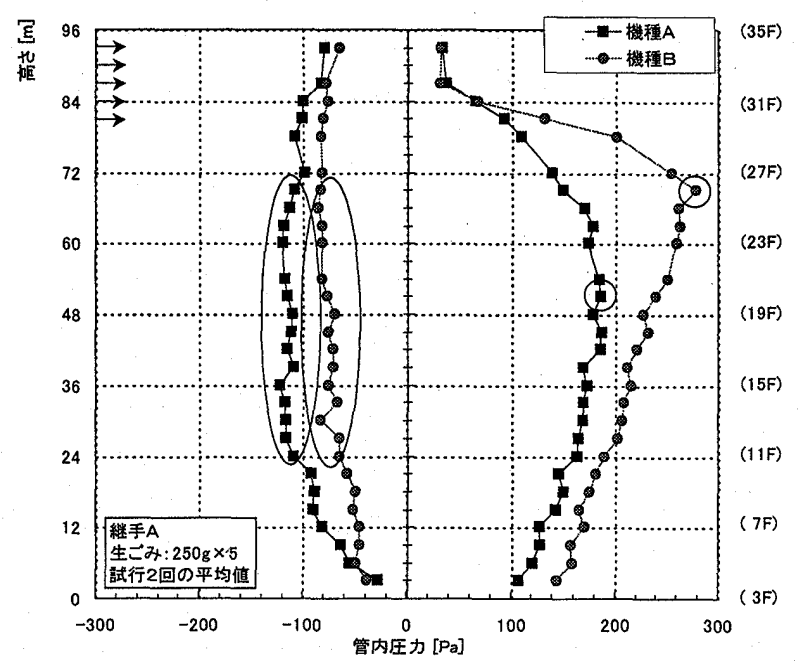

图 7.ディスポーザ機種による圧力分布の比較

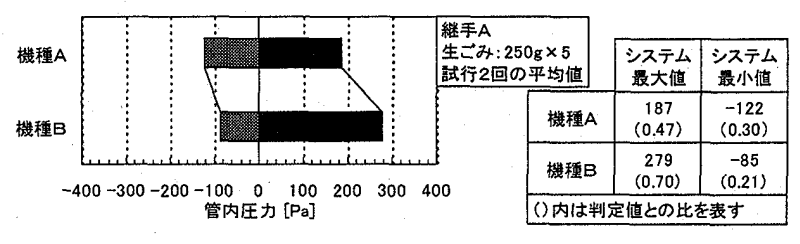

图８ディスポーザ破厒粒度と排出特性の圧力影響 


\section{3 過負荷時と合流負荷時の逃がし通気管の影響}

生ごみ量を $250 \mathrm{~g}$ から $500 \mathrm{~g}$ に増加させた場合(継手 $\mathrm{A}$, 単独過負荷 条件 (生ごみ量 $500 \mathrm{~g} の 5$ 個同時排水))の, 最下階 4 階の管内圧力変

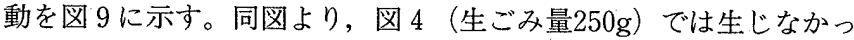
たが，機種 Bでは65秒に，参考として行った機種 A では55秒に，大 きな正圧変動が生じる。これは参考文献10)でも指摘されたように， 排水立て管流下中に破研厨芥と水が分離した後，脚部に先に堆積し た破碎噼芥に排水が衝突する，超高層でのディスポーザ排水に特有 の現象である。

図10の最大正圧分布は，この単独過負荷条件における脚部の逃が し通気管の影響を示したものである。大きな正圧変動が生じると， システム最大值は最下階でみられる。逃がし通気管により，最下階 の最大正圧は $+356 \mathrm{~Pa}$ から $+264 \mathrm{~Pa}$ に減少しており, 92Paの緩和が みられた。

図11は，II系統の合流用排水時に，I 系統を生ごみ量 $250 \mathrm{~g}$ で 5 個 同時排水した場合（合流負荷条件（表 3 ））の，逃がし通気管の影響 を確認したものである。同図より，この程度の負荷条件では大きな 正圧変動が生じず，システム最大値は最下階 4 階で生じず，同階の 正圧は $13 \mathrm{~Pa}$ 緩和した程度であった。これより，2つの実験による最 下階の正圧緩和は13 92Pa であり, 逃がし通気管の効果は判定值の 3 23\%と顯著には確認できなかった。

\section{4 供試オフセット配管と排水横主管の搬送性}

3.2 排水負荷条件での, 排水横主管内の搬送速度を求め, 四12に 示す。同図には, 参考文献10)での搬送速度約 $0.6 \mathrm{~m} / \mathrm{s}$ も参考に示し たが，今回のオフセットの流下前での $0.54 \sim 0.60 \mathrm{~m} / \mathrm{s}$ とほぼ一致す る。オフセットの流下後には, 搬送速度が $0.80 \sim 0.87 \mathrm{~m} / \mathrm{s}$ に達し, $0.26 \sim 0.27 \mathrm{~m} / \mathrm{s}$ の加速効果がみられる。これは, 脚部後でみられる; 破砝剭芥を後段の水が押し流す堰状流れが，オフセット流下時に堰 が水と混合して性質が弱まり, 横搬送がスムーズに行われるためで ある。オフセット後から段差配管を経由し，排水横主管の後半では $0.42 \sim 0.50 \mathrm{~m} / \mathrm{s}$ まで低下する。この值は, 参考として HASS206の横 管での必要最小流速 $0.6 \mathrm{~m} / \mathrm{s}$ と比較すると厳しい值となった。しか し，排水横主管内の残留物は卵殼の一部（写真 1）であり，堰状墛 芥は滞留せず排水妌まで搬送された。これは, HASS206の必要最小 流速の対象である砂と比べで煋状㞛芥の密度が小さいためと推 察される。卵殼が同写真のように残留し易いのは, 欴芥の中で比較 すると密度が大きいためと推察される。長期使用による麻芥の残留 状況を明確にすることはできなかったが，使用初期の搬送性能は確 保できた。

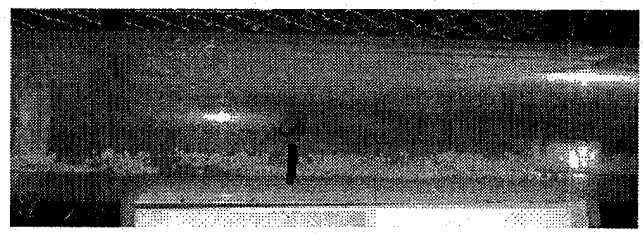

写真 1 卵の殻の残留例

\section{4.まとめ}

高さ $90 \mathrm{~m}$ (32層)，排水横主管長さ $90 \mathrm{~m}$ 規模の伸頂通気方式の超高 層集合住宅用ディスポーザ排水配管システムについて，最大同時排

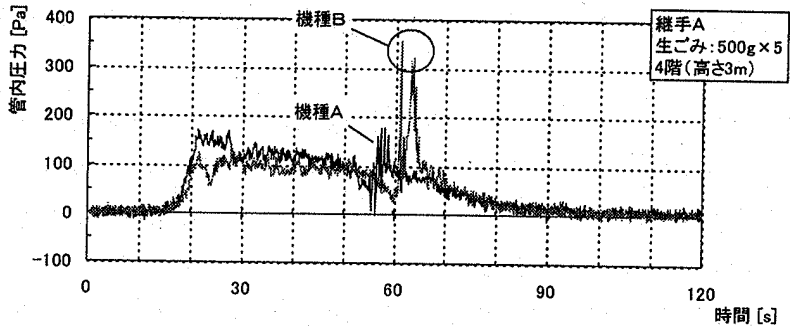

図 9 過負荷時における最下階 4 階の正圧変動現象

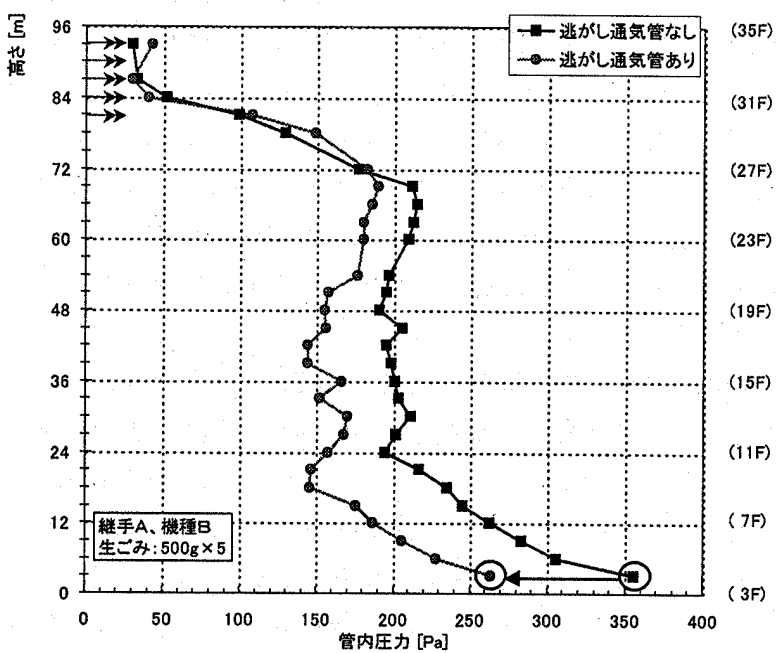

図10＼cjkstart過負荷時における逃がし通気管の正圧影響

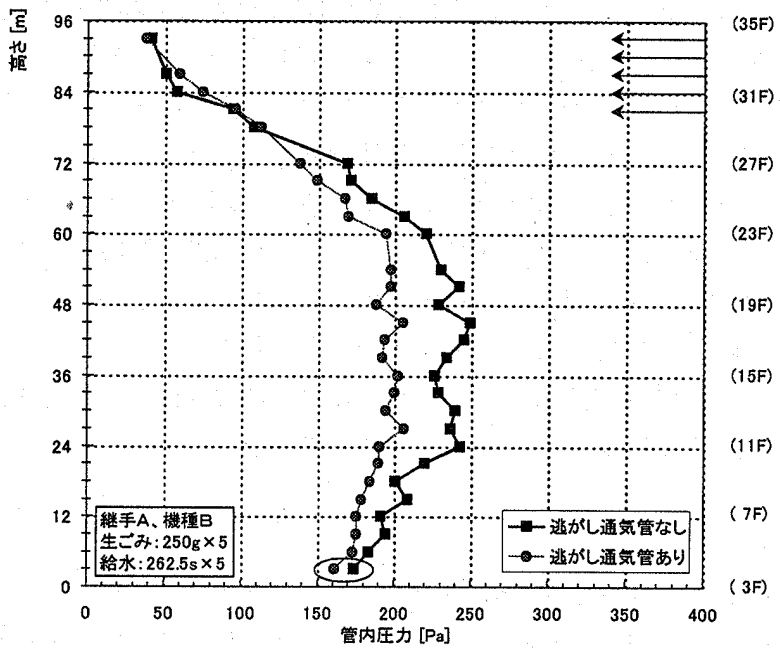

図11＼cjkstart合流負荷時における逃がし通気管の正圧影響

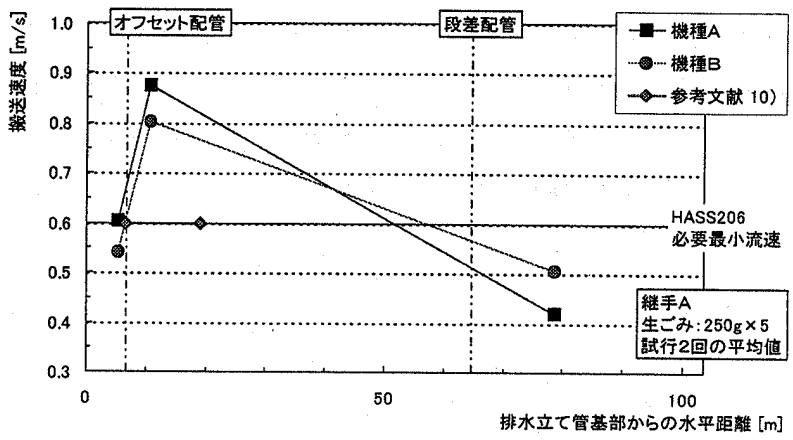

図12＼cjkstart排水横主管位置による搬送速度影響 
水負荷を想定した排水実験を行った結果, 性能試験法策定と設計に 資する以下の知見を得た。

(1) 市販の代表的な 3 種類の排水用特殊継手と 1 種類の従来型 ST 継手を用いた排水システムの性能評価を, HASS218の性能判定基 準（管内圧力 $\pm 400 \mathrm{~Pa}$ 以内）により行った。その結果, 従来型 ST 継手のシステム最小值が最も大きく基準値の73\%に達したが，排 水用特殊継手では $21 〜 30 \%$ と $1 / 4$ 程度におさまった。負圧緩和設計 には，特殊継手排水システムの採用は有効である。

(2) 市販のディスポーザの中から破砕粒度と排出特性を指標に 2 種 類を用いて，機種の違いが排水システム性能に及ぼす影響を調べ た。その結果，破砕粒度が粗く（メジアン粒径 $2.0 \mathrm{~mm}$ ) 破砕時間 が短い（破砕時間 $t=40[\mathrm{~s}]$ ) 機種のシステム最大值が最も大きく 基準值の $70 \%$ に達したが，破砕粒度が細かく（メジアン粒径0.6 $\mathrm{mm}$ 未満) 破砕時間が長い $(t=76[\mathrm{~s}])$ 機種では $47 \%$ と $1 / 2$ 程度に おさまった。正圧緩和設計には,生ごみ排出が緩やかなディスポー ザの選定は有効である。

（3）排水立て管基部に逃がし通気管を設置し，生ごみ量を 2 倍とし た過負荷， 2 系統の排水立て管から排水を合流させた合流負荷を 与え, 逃がし通気管の有無が排水システム性能に及ぼす影響を調 べた。その結果, 逃がし通気管がある場合はない場合と比べて, 排水立て管最下階の正圧を $13 \sim 92 \mathrm{~Pa}$ 緩和した程度であり, 効果は 顕著には確認できなかった。下層階の正圧が増大する場合の対応 として, 今回のような逃がし通気管の設置に大きな効果は期待で きない。

(4) オフセットを有する排水横主管の性能評価を, HASS206の必要 最小流速 $0.6 \mathrm{~m} / \mathrm{s}$ を参考に行った。その結果, 排水立て管基部直後 は搬送速度 $0.54 \sim 0.60 \mathrm{~m} / \mathrm{s}$ であったが，その後のオフセット通過 後では0.80 0.87m/sに達し加速効果がみられた。また，排水横 主管の後半では $0.42 \sim 0.50 \mathrm{~m} / \mathrm{s}$ まで低下し参考值以下であった が，堰状厨芥は排水栟まで搬送できた。排水横主管内の搬送性能 を高めるためには，オフセットの計画は有効である。

今後は，実在建物での性能検証や排水負荷の実態調查を行うとと もに，卵殼等の残留物や付着スケールによる排水性能の劣化度合も 考慮した性能検証手法を検討する予定である。

\section{謝辞}

本研究は，旧建設省建築研究所の委託により「ディスポーザーに よる生ごみリサイクルシステム研究会（委員長：前島健, 事務局： (俱日本建築センター)」内に設けられた「超高層排水配管赛験 WG (主查：舆水知)」の活動の一環として行ったものである。委員各位 に感謝の意を表します。並びに, 実験タワ一を利用させて戴いた都 市基盤整備公団総合研究所技術センターの方々, 有益な助言を戴い た単管式排水システム協会の方々，実験や生ごみ製作に協力して戴 いた方々に記して感謝の意を表します。
注 1) 11 機種のうち, 3 機種がメジアン粒径 $0.60 \mathrm{~mm}$ 未満のため, 最小篩 0.60 $\mathrm{mm}$ の透過率が最大のものを細かい機種（機種 A) とし， 3 機種がメジ アン粒径 $1.7 \mathrm{~mm}$ 程度のため, 最大穊 $3.35 \mathrm{~mm}$ の残留率が最大のものを 粗い機種（機種 B）とし，選定した。

注 2 ）既往調查 ${ }^{7)}$ よ，ディスポーザ使用水量は $5 \mathrm{~L} /(\mathrm{d} ・$ 人) であった。

注 3 ）ディスポーザ運転時間は37.5秒と表 1 の破砕時間に比べて短いが, 実際 には投入生ごみのほとんどが時間内に破砕できることを確認したので， 運転時間は給水時間と合わせた。

注 4 ）ディスポーザ排水の HASS206必要最小流速への適用性については, 堰 状流れの解明が不充分であるため，今後の課題とする。

\section{本論文に関連した口頭発表および委託研究報告}

1）大塚雅之,他：超高層住宅用ディスポーザ排水配管の実験的研究（その 1 . 排水継手による排水能力八の影響), 日本建築学会大会学術講演梗概集, D-1卷, pp.581-582, 2000年

2）新村浩一,他：超高層住宅用ディスポーザ排水配管の実験的研究(その 2 . ディスポーザによる排水能力及び搬送性能への影響)，日本建築学会大会 学術講演梗概集, D-1巻, pp.583-584, 2000年

3）長野晃弘，他：ディスポーザ排水システムに関する実証的研究（その 4 . 超高層集合住宅排水配管実験・排水継手の影響), 空気調和・衛生工学会 学術講演会講演論文集, III巻, pp.1737-1740，2000年

4）新村浩一，他：ディスポーザ排水システムに関する実証的研究（その 5 . 超高層集合住宅排水配管笑験・ディスポーザの破砕粒度の影響), 空気調 和・衛生工学会学術講演会講演論文集, III卷, pp.1741-1744, 2000年

5）建設省建筑研究所, 他：ディスポーザーによる生ごみリサイクルシステム の開発 (システムの有効性に関する実証的研究) 平成 9 年度 平成11年度 報告書, pp.159-295，2001年

\section{参考文献}

6）環境庁：環境白書 (平成12年版, 総説)，p.138，2000年，侏ぎょうせい

7）生ごみリサイクルシステム研究会：ディスポーザーによる生ごみリサイ クルシステムの開発，p.127，1999年，椇）日本建築センタ一

8）例之ば, 河村憲彦, 他：高層集合住宅のディスポーザ特殊継手排水システ ムに関する研究（その1．立て管径 $80 \mathrm{~A}$ システムでの排水性能）, 空気調 和・衛生工学会学術講演会講演論文集, III巻, pp.1761-1764, 2000年

9）仙石正雄, 安部嘉孝, 他：高層集合住宅のディスポーザ排水に適する排水 立て管システムの検討, 空気調和・衛生工学会学術講演会講演論文集, III 巻, pp.1757-1760, 2000年

10）大塚雅之,他：超高層集合住宅ディスポーザ排水配管システムに関する実 験研究 (その 1 . 基本配管システムの初期性能), 空気調和・衛生工学会 学術講演会講演論文集, II 巻, pp.1085-1088, 1999年

11）米田千瑳夫,他：超高層集合住宅ディスポーザ排水配管システムに関する 実験研究 (その 2 . 排水横主管と排水立て管系統合流), 空気調和・衛生 工学会学術講演会講演論文集, II巻, pp.1089-1092，1999年

12）高橋秀樹, 仙石正雄 : 排水技術の動向(4)特殊継手排水システム, 空気調和 衛生工学，第75巻第 3 号，pp.41-44，2001年

13）興水 知, 他：ディスポーザの破砕性能と排水特性および性能評価に関す る研究, 空気調和・衛生工学会論文集, No. 80, pp.59-68, 2001年

14）空気調和·衛生工学会：HASS206「給排水設備規準・同解説」, p.79, pp. 227-231，2000年

15）空気調和·衛生工学会：HASS218「集合住宅排水立て管システムの排水能 力試験法」, p.4, 2000年

16）金子順也，他：SI 住宅における横枝管排水性能に関する研究（その 7 . ディスポーザを用いた台所流し排水性能について), 空気調和・衛生工学 会学術講演会講演論文集, II 巻, pp.1121-1124，2001年

17）都市基盤整備公団総合研究所：集合住宅の生ごみ処理方式に関する研究 (その 3 ) 生ごみ処理機の利用状況及びディスポーザ排水性能試験法の立 案, pp.73-94，2001年 